\title{
Towards a Realist Criminology: Review of Roger Matthews (Editor) What Is to Done about Crime and Punishment? Towards a "Public Criminology". London: Palgrave Macmillan, 2016
}

\author{
Christopher Bagley \\ Faculty of Social, Human and Mathematical Sciences, University of Southampton, Southampton, UK \\ Email: Chrisbagley2@gmail.com
}

How to cite this paper: Bagley, C. (2018) Towards a Realist Criminology: Review of Roger Matthews (Editor) What Is to Done about Crime and Punishment? Towards a "Public Criminology". London: Palgrave Macmillan, 2016. Open Access Library Journal, 5: e4376.

https://doi.org/10.4236/oalib.1104376

Received: January 25, 2018

Accepted: February 20, 2018

Published: February 23, 2018

Copyright $\odot 2018$ by author and Open Access Library Inc.

This work is licensed under the Creative Commons Attribution International License (CC BY 4.0).

http://creativecommons.org/licenses/by/4.0/

\begin{abstract}
This review of the 11 chapters in this overview of a "realistic" approach to criminology, recommends this book as a text for use in graduate courses in criminology, public policy and the sociology of deviance. We focus in particular on chapters which advocate legal reforms on behalf of women forced to work in prostitution, and which elaborate the approach of Critical Realism as a model of social research for the emancipation of oppressed minorities.
\end{abstract}

\section{Subject Areas \\ Criminology, Sociology}

\section{Keywords}

Criminology, Critical Realism, Sex Work, Cybercrime, White Collar Crime, Prison Reform

\section{Introduction}

This interesting and valuable collection of essays and reviews on how societies define crime, and treat and process criminals, responds to the claim that: “... criminology is becoming a socially and politically irrelevant, despite its exponential expansion as an academic discipline." The 11 essays counter this "irrelevance" by addressing the question "what is to be done" in relation to a number of issues associated with crime, and how different cultures frame policies to pre- 
vent and "punish" its salient crimes. Most of the authors of the chapters are British, with a third coming from America, writing about North American issues. There is a unity of purpose in the policy analyses-on gang-related violence; domestic violence; crime prevention; prison reform; drugs policy; white collar crime; cybercrime; and policies which may protect women on whom prostitution is imposed. The common thread linking these perspectives is that of humanistic treatment of both offenders and victims, and social reforms which can diminish the costs that deterring and treating crime imposes on every society. The theoretical approach linking the papers is that of realism, considering empirical findings not on terms of grand theories of deviance, but in terms of how crime impacts the lives of ordinary people, and how criminals and potential criminals can be detected and reformed, and how ordinary people can be protected from remoter criminal enterprises such as cybercrime, and white collar crime.

The authors of these chapters strive not only to make their social science investigations relevant for their respective cultures, leading to advocacy for policy change: they also try and establish the global or transcultural lessons from their case studies. The authors also describe past initiatives which have been successful in diminishing crime rates in adolescents and adults, in ways which have been highly cost-effective. A dollar spent today on reform and intervention often has a 100 percent return in a decade, when the costs of prevented incarceration are taken into account. This public health approach is most vividly illustrated in the chapters on youth violence, and drugs policy, but in theory, applies to many other types of crime.

\section{The Chapters Considered in Detail}

For this British reviewer, one of the most interesting chapters is Elliott Currie's “The violence divide: taking 'ordinary' crime seriously in a volatile world”. From his Californian perspective (at the University of California, Irvine), Currie shows that gang violence amongst youth is, ultimately, a symptom of the world's violence which is both caused by, and serves, the neoliberalist agenda of capitalist control. He argues that: "Understanding the depth and spread of violence in our time-and its links to the depriving and disrupting forces of 'lidless' capitalism-calls for measures that look simultaneously at levels of violence and levels of incarceration, especially in those countries like USA.. Brazil or El Salvador where the growth of incarceration in recent years has been massive" (p. 17). The neoliberalist agenda is concerned (through its so-called "criminal justice" policies) "with the immediate goal of the social control of disadvantaged and dispossessed populations" (p. 19). Currie advocates taking back "liberalism" from the neoliberals, instead seeking policies which liberate economically poor individuals from the self-defeating rituals of crime and interpersonal violence. At the present time California imprisons ten times the proportion of young men as do European countries. Most of these imprisoned men are black, and there is a 
strong element of racism in America's system of policing and social control. Within-culture violence in America's black community is implicitly tolerated however, and in America each year "we lose eight thousand black lives a year to homicide" (p. 25).

Currie concludes his chapter: "We need, in short, to develop ways of fostering a criminology that is more than a relatively passive witness to the destruction wrought by contemporary global forces, and much less an accomplice ... [a criminology] that vigorously steps up to take on the job of combating those forces and dedicating itself unapologetically to the reduction of needless pain, fear and injustice around the world" (p. 29).

In their chapter on Domestic Violence, British sociologists Nicole Westmarland and Liz Kelly (from universities in Durham and London, UK) analyse their country's data on the murder of women: the large majority were killed by their partner or ex-partner. This statistic raises issues of sexism and male hegemony. The authors give data from an intervention project they have developed which uses a multiagency approach with men who have been violent towards their partners, and who were at risk of inflicting more serious violence. This programme was successful after 12 months in reducing violent actions, though whether it would diminish life-threatening violence in the long run awaits more systematic enquiry. At the societal level the authors advocate a more general attack on the value base which passively allows (or encourages) male sexism whose extreme element is the act of murder.

In a lengthy chapter Nicholas Tilley (from University College, London) makes the case for "middle-range radical realism for crime prevention", through the development of localised, community-focussed crime prevention programmes. "Realism" in the community context means the acknowledgement of the practical realities of clusters of poor housing and poverty, which feed youth rebellion. The "realistic" solution is one of diversion, giving such youth practical avenues for achievement of legitimate goals. These "middle range" policies do not aim to change the social structures which cause poverty, however.

Ben Bowling (from King's College, London) and his colleagues focus on policing, from their experience of Britain and Canada. Police, as Maurice Punch argued are "a secret social service", concerned as much with helping people as with controlling them [1]. In the realist model police operate at the community level, as youth workers as well as agents of social control. Police in this model are accountable to the communities they serve, and are not remote agents to be shunned and feared.

Francis Cullen (from the University of Cincinatti) and his American colleagues focus on "Seven ways to make prison work". Too often men and women leave prison as broken individuals, entering the downhill pathways of further crimes, and addictions. The programme of reform outlined by these authors is:

1) Make prisons less crowded-little can be done when prisons emulate zoolike conditions which provoke interpersonal violence. 
2) Make it possible for inmates to earn rewards-programmes of behaviour management can be run on classic behavioural psychology principles, in which prisoners are trained to be sociable and co-operative.

3) Use social science models to improve the conditions of confinement. This means evaluation and experiment concerning programmes that have intended goals.

4) Give the public what it wants-a combination of containment and reform, with low recidivism rates. A small proportion of prison budgets spent on social experiments could be hugely cost effective if such programmes reduce reoffending.

5) Make the Wardens accountable for correcting offenders. Prisons, like schools, should be evaluated on the ways in which they reform prisoners. Wardens should be highly trained in administrative sciences, and well-rewarded for success.

6) Use the risk-need-responsivity (RNR) model to rehabilitate prisoners. This is well researched and has proven efficacy.

7) Teach Prison Officers to be change agents. These officers are not "screws" who control lock-down, but are agents of the Warden, social workers as well as agents of social control. The prison, these authors conclude, is a complex social system and should be understand sociologically in terms of its values, norms and rituals. They are places of reform, not of punishment. "Deprivation of liberty is punishment enough", as prison reformers have frequently observed [2].

This lengthy chapter is abundantly referenced, and makes an excellent and cogent case for the use of social science disciplines as agents in prison reform, and the liberation of men and women from the chains of crime.

In the following chapter the British criminologist Caroline Chatwin (from the University of Kent) gives an outline of "Five steps towards a more effective global drug policy". Chatwin shows, first of all that America's "war on drugs" has not only failed, but has had many negative impacts, needlessly sending impoverished young men to prison for long periods, and allowing the oppression of ethnic groups. She argues for a global policy concerning drugs, their manufacture and refinement, and their transportation-in ways which protect individuals (e.g. legalisation of soft drugs), and undermine the demand for drugs from impoverished classes.

Fiona Haines (University of Melbourne) addresses the difficult problem of crimes committed by businesses and white-collar individuals. She writes of the "hegemony" of classes emancipated by neoliberal policies, for whom amassing wealth by quasi-legal means is at the expense of social and economic equality, and thus contributes to the genesis of blue-collar crime in manifold ways. Addressing the power of the neoliberal elites is not easy, but must be addressed.

Michael McGuire, an international consultant and expert on cybercrime, analyses a special type of white collar crime whose exponential growth in the age of electronic communications rivals the "profits" made from quasi-legal white 
collar crime, and greatly exceeds the diversion of taxable revenue which bluecollar crime involves. Fraud perpetrated by electronic methods is paralleled by the exploitation of minors in the crime of child pornography transmitted via the web. McGuire adds to the list of "computer crimes" the cyber attacks on domestic infrastructure, which may amount to a form of international terrorism. Cybercrime is growing, and will increase its threat as the use of electronic devices and media increases. He concludes that such crime is technology dependent, and it will thus be brought down through preventive technologies which can both check and capture the cyber-criminals.

\section{Sexual Exploitation and the Approach of Critical Realism}

Through work in policies to end sexual exploitation through prostitution [3] [4] I have a special interest in two chapters in Matthews' edited book: Chapter 4 by John Pitts (University of Bedfordshire) on "Critical realism and gang violence"; and Chapter 11 by Helen Johnson and Roger Matthews (University of Kent, UK) on the "Nordic model" which protects women by criminalising male buyers of sex, but not the women involved, who are all too often victims of trafficking, and of previous (or current) child sexual abuse.

In their chapter "Addressing prostitution: The Nordic model and beyond," Johnson and Matthews offer a comprehensive and sympathetic review of the Nordic model, referring in particular to research from Sweden, laying emphasis on strategies for helping girls and women to exit imposed sexual labour, and on preventing recruitment and entry to such labour, which has been shown to harm many of the girls and women upon whom it is imposed. The law, in Sweden and elsewhere they argue, is a starting point in this process and is not a comprehensive solution, if work for rescue and rehabilitation is under funded or undeveloped.

Johnson and Mathews conclude:

"As we learnt from anti-smoking campaigns an effective strategy needs to engage with the issue at a number of different levels. There is a requirement to develop formal legal responses alongside more informal strategies that connect with the hearts and minds of the general public. Introducing the Nordic model in countries like the UK would no doubt be a very positive step, but for the legislation to be effective a number of other changes in policy and practice need to take place." (p. 304)

The chapter by John Pitts, "Critical realism and gang violence" is a critical realist approach to street gangs that emphasises models for public policy which could apply equally well to prostituted "sex work." Since I am an enthusiastic supporter of the critical realist approach to issues in the lives of disadvantaged groups, including the sexual violence imposed on girls and women, following the pioneering work of Priscilla Alderson [5] [6], I recommend Pitts' chapter as an exemplar of such research analysis. Sawyerr and Bagley [7] have elaborated the 
principles of the critical realist approach in sociological research elsewhere, and we have applied it in various settings concerning children and youth [8].

Critical realism is a value-based approach to social research, in which the researcher has a clearly elaborated value commitment which motivates the undertaking of the research, and the interpretation of the research findings (usually using qualitative case studies). Critical realism is ontologically grounded on the recognition of the "absent actors," the ignored, invisible people whose real lives and sufferings society ignores. Abused and disadvantaged children form the ground of much critical realist work [7]. Their lives, needs and struggles are elaborated in critical realist accounts, which identify the power systems in social structures which deny their rights. A process of morphogenesis is advocated, in which the voices of the oppressed become dialectically engaged with power systems in seeking social change [9]. It seems to me that the situation of sexually abused children and adult women (abused through the imposition of prostituted sexuality) ideally fits the critical realist model of emancipation from a kind of slavery.

\section{Conclusion}

In conclusion, I can warmly recommend this book as a valuable resource for those who study deviance, criminality, and humanistic models of social intervention and social reform. It could, with other resources, form an important text for study by graduate students.

\section{References}

[1] Punch, M. (1979) Policing the Inner City. Palgrave MacMillan, London. https://doi.org/10.1007/978-1-349-03991-3

[2] Adams, R. (1994) Prison Riots in Britain and the USA. MacMillan, London. https://doi.org/10.1007/978-1-349-23587-2

[3] Bagley, C. (2017) Book Review Article: Banyard's Pimp State: Sex, Money and Equality. Dignity. Journal of Sexual Exploitation and Violence, 2, 1-12. https://doi.org/10.23860/dignity.2017.02.02.06

[4] Bagley, C., Khadri, S., Shanaz, A., Simkhada, P. and King, K. (2017) Commercialized Sexual Exploitation of Children, Adolescents and Women: Health and Social Structure in Bangladesh. Advances in Applied Sociology, 7, 137-150. https://doi.org/10.4236/aasoci.2017.74008

[5] Alderson, P. (2013) Childhoods Real and Imagined: An Introduction to Critical Realism and Childhood Studies. Routledge, Abingdon.

[6] Alderson, P. (2016) The Politics of Childhoods Real and Imagined: Practical Application of Critical Realism and Childhood Studies. Routledge, Abingdon.

[7] Sawyerr, A. and Bagley, C. (2017) Equality and Ethnic Identities: Studies of SelfConcept, Child Abuse and Education in a Changing English Culture. Brill-Sense Education Series, Leiden. https://doi.org/10.1007/978-94-6351-080-6

[8] Bagley, C., Sawyerr, A. and Abubaker, M. (2016) Dialectical Critical Realism: Grounded Values and Reflexivity in Social Science Research. Advances in Applied Sociology, 6, 400-419. https://doi.org/10.4236/aasoci.2016.612030

[9] Archer, M.A. (2012) The Reflexive Imperative in Late Modernity. Cambridge University Press, Cambridge. https://doi.org/10.1017/CBO9781139108058 